\title{
Twenty Years of Literature at University. An Insider's Perspective ${ }^{1}$
}

\author{
ANNELI NIINRE
}

\begin{abstract}
Taking the Estonian philology BA curriculum as an example, the article analyses the changes in literature courses in 1998 and 2018 at Tallinn University (former Tallinn Pedagogical University). The year 1998 marks the beginning of my student life, the year 2018 marks the last full year as a lecturer. The 20-year period shoes vividly the changes that have taken place in the Estonian educational system. The overview is based on Estonian literature and world literature courses included in the Estonian philology BA curriculum. The article gives an overview of the periods, topics, themes, authors, theories and methods discussed in literature courses. The emphasis is on the changes that have taken place.
\end{abstract}

Keywords: literary pedagogy; university; curriculums; Estonian literature; world literature

\section{Introduction}

Over the last years more and more attention has been paid to literature: the way literature is being taught at schools; ${ }^{2}$ the position of literature, more specifically Estonian literature, has been the subject of debates, for example, the round-table discussion "Is Estonian literature leaving school?" held in January 2019. ${ }^{3}$ The round table included teachers of Estonian language and literature, a librarian, a representative of the Ministry of Education and Research and others. The main issue discussed was the fact that there are fewer and fewer lessons dedicated to (Estonian) literature and also the fact that literature tends to dissolve in other subjects, e.g. is part of cultural studies, etc. ${ }^{4}$

1 This study was supported by the Estonian Ministry of Education and Research (IUT 18-4), and by the European Union through the European Regional Development Fund (Centre of Excellence in Estonian Studies). This article discusses more thoroughly the issues addressed in Kõvamees 2019b.

2 About literature teaching at schools in the $20^{\text {th }}$ century see Talviste 2019.

3 The event can be found here: https://kultuur.err.ee/902767/err-ee-video-umarlaudkas-eesti-kirjandus-lahkub-koolist

4 About the issues in literature teaching, see Õpetajate Leht 2019. 
NIINRE

While the problems of teaching literature at schools have been addressed, the situation at universities is largely unmapped. Taking the Estonian philology BA curriculum at Tallinn University (till 2005 Tallinn Pedagogical University $^{5}$ ) as an example the article compares literature courses in the curriculums of the year 1998 and 2018. These are personal milestones: the year 1998 marks the beginning of my student life as the year 2018 marks the last full year as a lecturer. Therefore, I can say that I have experienced the turbulent times in the Estonian educational system from both sides. The analysis concentrates on Estonian literature and world literature courses included in the Estonian philology BA curriculum. Which periods, topics, themes, authors have been taught? What kind of theories/methods have been used? What kind of changes have taken place?

Some background information. In 1998 there were the chair of Estonian literature and the chair of world literature at the department of philology at Tallinn Pedagogical University. During the period of twenty years there have been quite significant changes: in 2005 when Tallinn Pedagogical University was renamed Tallinn University, the chair of Estonian literature and literary theory was founded, meaning the chair of world literature was abolished. Three years later the system of institutes was introduced, hence, the Institute of Estonian Language and Culture was founded. In 2015 the School of Humanities was founded uniting all the institutes dealing with humanities. Therefore, today there are study areas, e.g. Estonian language and culture, Cultural theory, Western European studies, Russian and East European studies, etc. It is noteworthy that 'literature' has vanished from the labels, being now part of cultural studies. During these changes the number of teaching staff of literature courses has declined significantly: for example, in autumn 2019 there were 2,5 persons teaching Estonian literature courses (not including visiting lecturers). Thus, twenty years ago there were two chairs teaching literature courses, while today there are only a few lecturers left. ${ }^{6}$

In addition to the changes at the institutional level, there have also been significant changes in the Estonian philology BA curriculum. In 1998 the fouryear BA study program was introduced, which replaced the previous five-year program. In 2002 the three-year study program was introduced as the Bologna system replaced the previous system. Today the three-year BA curriculum

\footnotetext{
Several universities and institutes were united that formed Tallinn University on March 18, 2005. More information can be found here: https://www.tlu.ee/en/history

6 As the article is based on the Estonian philology curriculum, it represents the number of teaching staff directly associated with the curriculum and connected to the study area Estonian language and culture.
} 
Twenty Years of Literature at University. An Insider's Perspective

of Estonian philology has two main fields of study: Estonian language and literature and the reviewer-editor. ${ }^{7}$ The curriculum is divided into modules, e.g. university-wide courses (üleülikoolilised ained in Estonian), Estonian language, Estonian literature, Introduction to Humanities. ${ }^{8}$

It may be said that similarly to the changes at the institutional level, the changes in literature courses are also dramatic when the curriculum of 1998 and the current curriculum are compared. In 1998 there were 9 world literature courses and 12 Estonian literature courses, plus Estonian folklore, Introduction to Literary Studies, which, for example, addressed the term 'fiction', introduced the terms and methods used in literary studies, introduced different genres and their characteristics; Introduction to Literary Theory, the Historiography of Literary Studies, the Metrics, introducing the principles of poetry and also giving an overview of notable Estonian poets and trends in Estonian poetry; the course titled the Analysis of Literary Works and special courses and seminars. It was, for example, possible to take special courses on various theories or theoretical aspects, e.g. the course dedicated to Derrida and deconstructivism or the course about feminist literary theory. Although in these courses lecturers introduced the principles and background of a given theory, the students themselves had to read and analyse theoretical texts. Thus, in total 30 literature courses. These numbers include both compulsory and elective courses. Today there are in total 5 literature courses. All these courses are compulsory, as there are no more elective courses in the curriculum.

\section{Literature Courses: Estonian Literature}

The curriculum in 1998 aimed to give a thorough overview of the history of Estonian literature, therefore, courses like the Older Estonian Literature and Estonian Literature I-IV were included in the curriculum. In addition to Estonian literature courses, there was a course dedicated to Estonian folklore and a special seminar dedicated to the newest Estonian Literature. Thus, Estonian literature from the very beginning until the present day was covered.

7 The curriculum of the reviewer-editor aims to give a good knowledge of the Estonian language and also skills needed for working as an assistant who translates, reviews and edits various texts.

8 The curriculums can be found in print form in the case of the curriculum of 1998 (see Oppeteatmik 1998/99) and online in case of the current curriculum (see the study information system (ÕIS) or https://www.tlu.ee/ht/eesti-keel-ja-kirjandus\#oppekavaja--ained). 
NIINRE

The emphasis of Estonian literature courses was on literary history, various literary theories were briefly introduced and discussed. The Older Estonian Literature covered the very beginning of Estonian literature including, for example, religious writings, the Estophile Enlightenment Period, the works by Kristjan Jaak Peterson (1801-1822), Friedrich Robert Faehlmann (1798-1850) and Friedrich Reinhold Kreutzwald (1803-1882). The national epic Kalevipoeg (1862, Kalev's Son), the poetry by Peterson and mythical folk tales by Faehlmann were more thoroughly analysed. The course also included the works by Baltic German authors. As a common practise, the term 'literature' was treated broadly, meaning everything associated with Estonia and Estonians - chronicles, various texts that mention Estonians or texts that contain words and phrases in the Estonian-language - is considered part of Estonian literature when the beginning of Estonian literature is discussed. ${ }^{9}$ It is noteworthy that there was also a course dedicated to Estonian culture, which also addressed the earlier period of Estonian history and culture, thus also dealing with the Baltic German aspect in Estonian culture. Therefore, the earlier period was thoroughly discussed in the curriculum.

The course Estonian Literature II covered the period 1920-1940, the socalled golden period of Estonian literature, the time of the Estonian Republic. The canonical authors like A. H. Tammsaare (1878-1940), Marie Under (1883-1980), Betti Alver (1906-1989), Heiti Talvik (1904-1947), etc., were discussed but also for example short story writers Peet Vallak (1893-1959) and Karl August Hindrey (1875-1947). Besides canonical and today well-known authors, several peripheral authors and groups were also discussed, for example Erni Hiir (1900-1989) and the working Estonian idea (tööeestlus). ${ }^{10}$ The controversial Johannes Vares-Barbarus ${ }^{11}$ and his poetry were also addressed. This course intended not only to give an overview of the period but also aimed at analysing some works profoundly. For example, two whole seminars were dedicated to the analysis of the short story "Isa" (Father) by Hindrey. While in connection with Alver her poetry is usually in the centre of discussion, this course also analysed her prose, namely "Viletsuse komöödia” (1935, The Comedy of Misery).

\footnotetext{
9 About the definition of Estonian literature see e.g. Kõvamees 2019a.

10 The working Estonian was an idea in the 1930s, which set its aim to construct the national identity of Estonians by emphasizing work as the basis of the identity. See Liiv 2008.

11 A modernist poet in the 1920s and 1930s who was one of the leading figures in the Sovietization of Estonia.
} 
The following course, Estonian Literature III concentrated on a controversial period in Estonian culture - the 1940s and 1950s. Besides the authors who are today in the centre of a literary canon, e.g. exile writers Karl Ristikivi (1912-1977), Bernard Kangro (1910-1994) and Kalju Lepik (1920-1999), etc., canonical authors of the Soviet era were also discussed, e.g. August Jakobson (1904-1963) and his today largely forgotten plays Šaakalid (1952, The Jackals), Kaitseingel Nebraskast (1953, The Guardian Angel from Nebraska) and Suremine (1953, Dying), which represent the vulgar socialist realist satire; or Juhan Smuul (1922-1971) who's from today's viewpoint extremely controversial "Poeem Stalinile" (1949, Poem to Stalin) was analysed from various angles and the method of close reading was applied. His poem "Mina kommunistlik noor" (1953, I - Communist Youth) was introduced with the note to read it with impartial eyes, not to look for socialist realism but to read it as a text as any other. ${ }^{12}$ One of the ideas behind the course was to give a more open view of Estonian literature and emphasise the influence of historical background and the idea that concepts and the canon shift in time.

In addition to compulsory courses, there were special courses concentrating on specific aspects or periods, e.g. Estonian Children's literature, Baltic German literature, the seminar about Estonian short story, etc. The latter aimed at giving an overview of the history of the Estonian short story, introducing various authors and main trends while the theory of the short story was also introduced. Comparisons were made between Estonia and the rest of the world. Texts from various periods were analysed and compared, for example "The Fall of the House of Usher" by Edgar Allan Poe (1809-1849) and "Popi ja Huhuu" (Popi and Huhuu) by the Estonian short story master Friedebert Tuglas (1886-1971), underlining the motive of a house. In addition, the translations of Poe's short story by Johannes Aavik and Helga Kross were discussed. In addition to the well-known classics like "Maanaine" (Peasant Woman) by Peet Vallak and "Igapäevane lugu" (An Ordinary Story) by Juhan Liiv (1864-1913), authors from the margins were discussed, e.g. Lilli Promet (1922-2007) and Uno Laht (1924-2008). The seminar about Estonian short story course also emphasized the method of close reading while setting as its aim the introduction of the cultural-historical background.

It may be concluded that the Estonian philology curriculum gave a versatile insight into Estonian literature: both literary history and literary theory were discussed. There were courses aiming at giving an overview of the history of

12 Here and elsewhere materials from my personal archive are used (e.g. course programs, lecture notes, etc.). 
NIINRE

Estonian literature, which laid the foundation to the specific courses, which allowed a deeper insight. It is also worth mentioning that there was a variety of lecturers each having his/her own speciality and viewpoint, which enriched the way literature was analysed.

The contemporary curriculum has 4 courses dedicated to Estonian literature: Folklore and Older Estonian Literature, the Renewal of Estonian Literature, Estonian Literature in the Second Half of the $20^{\text {th }}$ century and Close Analysis of Literary Texts. All the courses except the last one aim at giving a general overview of Estonian literary history. For example, the course the Renewal of Estonian literature concentrates on the period from the beginning of the $20^{\text {th }}$ century till the year 1960 . The course gives an overview of main trends in Estonian literature during the period and introduces more thoroughly most notable authors and literary works, e.g. Tammsaare, Ristikivi, Kangro, Smuul, etc. During that course some literary texts are analysed in seminars, e.g. the short stories by Vallak and Hindrey, the novel Ma armastasin sakslast (1935, I Loved a German) by Tammsaare, the novel Hingede öö (1953, All Souls' Night) by Ristikivi. In connection with the analysis of literary works various literary theories are very briefly introduced. The only course specializing in literary theory is the course called Close Analysis of Literary Texts where various texts are analysed using different theories. Theoretical texts as well as fictional texts are read and analysed but the aim of this course is also a more general one, as theories are only briefly introduced, the course does not concentrate on one theory and its specifics.

\section{Literature Courses: World Literature}

The Estonian philology curriculum in 1998 also aimed at giving a thorough overview of the history of world literature. The same principles were applied: there were courses concentrating on giving an overview plus specific courses concentrating on various authors, topics, trends, etc. There were two main courses titled World Literature I and II, which gave the general overview of world literature. For example, World Literature II was dedicated to the $20^{\text {th }}$ century European and American literature. The course included topics like American poetry at the beginning of the $20^{\text {th }}$ century (Ezra Pound, $\mathrm{T}$. S. Eliot and Edgar Lee Masters were under closer inspection); the English novel at the beginning of the $20^{\text {th }}$ century, introducing not only the authors, e.g. Virginia Woolf, James Joyce, D. H. Lawrence but also themes, topics and methods, e.g. the stream of consciousness; Scandinavian literature in the $19^{\text {th }}$ and $20^{\text {th }}$ century (e.g. August Strindberg and Henrik Ibsen). The course was 
accompanied by the list of 35 authors and their major works of which 15 had to be selected and read. As a conclusion, the course gave a good overview of the $20^{\text {th }}$ century literature.

In addition to these general courses, there were various special courses, e.g. Trends in German literature, which compared the following books: Johann Wolfgang Goethe's (1749-1832) Die Leiden des jungen Werthers (1774, The Sorrows of Young Werther) and Ulrich Plenzdorf's (1934-2007) Die neuen Leiden des jungen W. (1972, The New Sorrows of Young W.); Adelbert von Chamisso's Peter Schlemihls wundersame Geschichte (1814, Peter Schlemihl's Miraculous Story) and Thomas Mann's (1875-1955) Tonio Kröger (1903); E. T. A. Hoffmann's (1776-1822) “Klein Zaches gennant Zinnober” (1819, Little Zaches, called Cinnabar) and Patrick Süskind's (born 1949) Perfume (1985). In addition to the analysis of these texts, the course also addressed themes like romanticism, the German romanticism, modernism, etc.

The course European Novel: from Renaissance to Modern Era set its aim to give a deeper insight into the trends in the European novel. The course gave a historical-cultural overview of the period under investigation discussing themes, topics and authors in French, Spanish, English and German literature. For example, in connection with Don Quijote (1585, Don Quixote) by Miguel de Cervantes (1547-1616) a modern, complex protagonist was discussed; the stream of consciousness was analysed in connection with English literature (e.g. Virginia Woolf's (1882-1941) Mrs Dalloway (1925)) and existentialism in connection with French literature (e.g. Jean Paul Sartre, Albert Camus). The course also set its aim to introduce the development of the novel as a genre, its roots and variations.

There were also special courses on Spanish, Austrian, Russian and Canadian literature and a course dedicated to the Beat generation, analysing for example Jack Kerouac's (1922-1969) On the Road (1957). Although Estonian (or any other literature) was always discussed in connection with trends in world literature, there was also a special course dedicated to the topic Estonian Literature in the Discourse of World Literature.

While twenty years ago there was a variety of courses on world literature, today there is only one course - World Literature. This course belongs to the module called Introduction to Humanities. The aim of the course is to give an overview of some of the central topics, forms and plots of world literature. The course concentrates on 7-10 works, which are analysed more thoroughly. The course includes Western literature (including Estonian literature), Middle East and Asian literature and also postcolonial literature. It is noteworthy that the course includes a wider range (Middle-East and Asian literature) but due to the time limit it is questionable how thorough is the insight into world literature. 
NIINRE

\title{
Conclusion
}

It may be concluded that changes in the field of literature teaching at university have been significant. The number of literature courses has declined dramatically and it may be said that today there is no variety. In the current curriculum the historical overview of literature definitely dominates as the curriculum of Estonian philology is aimed to give only a general overview of literature, the emphasis is on literary history, the theories and methods used depend largely on lecturers as there are no specific courses dedicated to literary theory nor introducing the basics of literary studies. Students merely get the general overview of Estonian literature, an extremely brief overview of world literature and one course specially dedicated to the analysis of literary works and theoretical texts. It is also worth mentioning that there used to be a number of lecturers, compared to the few today, each having his/her own speciality and viewpoint, thus enriching the insight into the literary world. The students are expected to continue their studies in the MA level, for example literary studies or the teacher of Estonian language and literature. However, in reality only a few continue their studies, thus it may be said that today those finishing the BA curriculum of Estonian philology have only the basic knowledge of literature.

These changes have taken place gradually, step by step we have found ourselves in the situation we are today. In some aspects the situation is similar to boiling the frog. If a frog is put suddenly into boiling water, it will jump out, but if the frog is put in tepid water which is then brought to a boil slowly, it will not perceive the danger and will be cooked to death. Today we can only wonder what could have been done differently and hope that these are not the last breaths of literature teaching in academic level in Estonia. At least those who have remained in the academic field are doing their best.

\author{
Anneli Niinre \\ anneli.niinre@gmail.com \\ Tallinna Ülikool \\ Humanitaarteaduste instituut \\ Narva mnt 29 \\ 10120 Tallinn \\ EESTI / ESTONIA
}


Twenty Years of Literature at University. An Insider's Perspective

\section{References}

Kõvamees, A. 2019a. Literature Defined by Language? Some Remarks on the Definition of Estonian Literature. - Interlitteraria, 24/1, 236-246. https://doi. org/10.12697/IL.2019.24.1.17

Kõvamees, A. 2019b. Kas eesti kirjandus on lahkumas academia'st? - Looming, 12, $1796-1798$.

Liiv, T. 2008. Elulähedus, vaimulähedus, võimulähedus. - Haridus, 5-6, 24-26.

Talviste, K. 2019. Traditsioon ja avangard eesti kirjandusõpetuse kujunemisloos. Philologia Estonica Tallinnensis, 4, 32-55. https://doi.org/10.22601/PET.2019. 04.02

Õpetajate Leht 2019 = Eesti keele aastal õpetajatega eesti keele ja kirjanduse ópetamisest. - Opetajate Leht 15.03.2019.

Õppeteatmik 1998/99 = M. Kõrvits, A. Monakov, I. Teiter, eds. Õppeteatmik 1998/99. Tallinn: TPÜ Kirjastus, 1998. 